J. Lake Sci. (湖泊科学), $2006, \mathbf{1 8}(4): 369-376$

http:// www. jlakes. org. E-mail: jlakes@ niglas. ac.cn

(c) 2006 by Journal of Lake Sciences

\title{
云南鹤庆盆地中更新世以来的狍粉记录及其植被与气候变化”
}

\author{
肖霞云 ${ }^{1,2}$, 沈 吉 ${ }^{1}$, 肖海丰 ${ }^{1,2}$, 童国榜 ${ }^{3}$ \\ (1: 中国科学院南京地理与湖泊研究所, 南京 210008) \\ (2: 中国科学院研究生院, 北京 100039) \\ (3: 中国地质科学院水文地质环境地质研究所, 正定 050803 )
}

摘 要: 通过对“中国大陆环境钻探计划”首钻一一云南鹤庆深钻前 $155 \mathrm{~m}$ 约 $800 \mathrm{ka}$ 以来的岩芯进行孢粉研究, 探讨了云 南鹤庆盆地中更新世以来的植被演替与古气候变迁. 研究表明鹤庆盆地周围山地的植被在约 $800 \mathrm{kaBP}$ 至 $6.98 \mathrm{kaBP}$ 之间 经历了以松为主的针叶林、山地针阔叶混交林、寒温性针叶林的多次相互演替; 从 $6.98 \mathrm{kaBP}$ 开始,植被发生了转折性变 化, 森林植被迅速退化, 以草本为主, 此时开始受到人类活动的影响, 人类活动表现在砍伐森林和种植农作物等方面. 与植 被演替相应的古气候可划分为五个大的阶段,包含多次冷暖、干湿旋回.

关键词:孢粉记录; 植被演替; 气候变化; 中更新世; 鹤庆盆地

\section{Pollen records and vegetation and climate changes in Heqing Basin, Yunnan Province since middle Pleistocene}

\author{
XIAO Xiayun ${ }^{1,2}$, SHEN Ji ${ }^{1}$, XIAO Haifeng ${ }^{1,2} \&$ TONG Guobang ${ }^{3}$ \\ (1: Nanjing Institute of Geography and Limnology, CAS, Nanjing 210008, P. R. China) \\ (2: Graduate School, CAS , Beijing 100039, P. R. China) \\ (3: Institute of Hydrogeology and Engineering Geology, CAGS, Shijiazhuang 050061, P. R. China)
}

\begin{abstract}
Vegetational succession and climatic change since middle Pleistocene in Heqing Basin in Yunnan Province are discussed according to the sporopollen analysis for the top $155 \mathrm{~m}$ length core and about 800 kaBP history from Heqing deep drilling core. This core is the first drilling core of Environmental Drilling Programme in Chinese continent. The results show that vegetation in the surrounding mountains in Heqing cathchment experienced many times changes among coniferous forest dominated by Pinus, montane coniferous and broadleaved mixed forest and cool temperate coniferous forest during the period about $800 \mathrm{kaBP}$ to $6.98 \mathrm{kaBP}$. From $6.98 \mathrm{kaBP}$ to today, vegetation has immensely changed, such as forest degraded quickly and vegetation dominated by herbs, when human activities have begun affecting vegetation. Human activities represent disafforestation and planting crops and so on. Climate corresponding to vegetation evolution may be divided into five stages and contains many times cool and warm, dry and humid gyrations since about $800 \mathrm{kaBP}$.
\end{abstract}

Keywords: Sporopollen record; vegetational succession; climatic change; middle Pleistocene; Heqing Basin

云南高原的气候主要受控于西南季风气候系统, 此外兼受西风带和青藏高原局地气候影响. 新生代以 来随着青藏高原的隆升, 该区发育了众多构造断陷湖泊 ${ }^{[1]}$. 由于湖泊沉积忠实地记录了流域气候与环境的 演变过程,并具有连续性好、分辨率高、包含信息量丰富等特点,近年来在全球变化和区域环境演化研究领 域发挥了愈来愈重要的作用 ${ }^{[2,3]}$. 西南季风区是我国生物多样性最丰富的地区, 垂直植被带发育, 从西双版 纳到玉龙雪山不足 $600 \mathrm{~km}$ 的范围内存在热带季雨林到现代高山冰川所有植被带, 是全球植被空间分布的

* 国家自然科学重点基金 (编号:40331003) 资助. 2005-08-22 收稿; 2005-09-22 收修改稿. 肖霞云, 女, 1977 年 2 月生, 博士研究生; E-mail: xyxiao@ niglas. ac. cn. 
浓缩 $^{[4]}$. 如此典型的植物多样性的由来过程可以从湖泊沉积档案中去寻找答案, 因此在西南季风区选择合 适湖盆, 通过实施湖泊钻探, 系统研究西南季风的形成、演化及气候特点, 了解冰期/间冰期西南季风的变化 及内部结构, 揭示西南季风演化与植被演替、环境变化的关系, 无论对高原隆升的气候环境效应, 以及全面 揭示亚洲季风对环境的控制和影响都具有十分重要的意义. 云南鹤庆盆地地处云南高原的西北部, 盆地内 堆积了厚约 $700 \mathrm{~m}$ 的松散湖相和河流相沉积, 保存有丰富的古环境信息, 是研究我国第四纪西南季风和湖 泊生态环境演变的有利地区之一 ${ }^{[5]}$. 湖相沉积物中的狍粉记录是地质时期古植被的表征和古气候信息的 可靠载体,通过狍粉记录可以恢复研究区的植被历史、重建古气候,进一步可以用于反映构造抬升、古季风 变化等方面. 本文属于“中国大陆环境钻探计划” 首钻一一云南鹤庆深钻的研究内容, 首钻总长 $737.72 \mathrm{~m}$, 这里先仅对上部 $155 \mathrm{~m}$ 岩芯进行狍粉研究,更深层位的狍粉研究结果以后会相继发表.

\section{1 自然地理概况}

鹤庆盆地 $\left(25^{\circ} 51^{\prime}-26^{\circ} 42^{\prime} \mathrm{N}, 100^{\circ} 06^{\prime}-100^{\circ} 29^{\prime} \mathrm{E}\right)$ 为构造断陷, 位于青藏高原东南边缘部位, 属滇西北 横断山余脉. 盆地面积约 $144 \mathrm{~km}^{2}$, 呈南北长条形展布, 与构造带走向一致, 南北长约 $22 \mathrm{~km}$, 东西宽约 6-10 $\mathrm{km}$, 地势低平, 海拔 $2193-2240 \mathrm{~m}$, 北高南低, 坡度约 $1^{\circ}-3^{\circ}$. 盆地四周有小溪、小河汇人, 中部低洼地积水 形成草海, 现在湖水变浅. 盆地东部有漾弓河自北向南流过,出盆地后折向东流人金沙江,成为金沙江水系.

该区夏季主要受来自孟加拉湾的暖湿气流影响,冬季受南支西风急流控制. 1 月均温 $6.3^{\circ} \mathrm{C}, 7$ 月均温 $19.2^{\circ} \mathrm{C}$, 年均温 $13.5^{\circ} \mathrm{C}, 1$ 月平均降水量 $2.4 \mathrm{~mm}, 7$ 月为 $229.3 \mathrm{~mm}$, 年降雨量 $1071 \mathrm{~mm}$, 雨量的年内分配主要 集中在夏季,占全年降雨量的 $80 \%-90 \%$.

盆地以北 $40 \mathrm{~km}$ 处的玉龙雪山，山地垂直植被发育. $5000 \mathrm{~m}$ 高度为雪线,树线位于大约海拔 $3900 \mathrm{~m}$ 左 右 (冷杉Abies 林上限), 它们之间主要为高山杜鹃灌丛, 嵩草高山草地, 高山砾石 (岩屑) 冻荒漠组成; 在海 拔 $3100 \mathrm{~m}$ 左右, 山地生境明显变为凉湿, 是为夏季云雾线分布所在, 这以上直到海拔 $3900 \mathrm{~m}$ 左右都为亚高 山寒温针叶林带 (云杉林和冷杉林) 分布的范围; $2800-3200 \mathrm{~m}$ 之间为山地针阔叶混交林, 主要树种有铁 杉、冷杉、石栋以及槭、桦等, 林下多有箭竹和杜鹃层片; $2800 \mathrm{~m}$ 以下为云南松 (Pinus yunnanensis) 林, 雪山西 北侧虎跳峡谷地气候偏干暖, 为干热河谷稀树灌木草丛 ${ }^{[4,6]}$.

\section{2 钻孔剖面特征与研究方法}

2002 年 7 月,由国家科技部和中国科学院联合支持的“中国大陆环境钻探计划”的首钻在云南鹤庆盆 地得以实施, 本次钻探首次在国内采用内衬管取芯的方法, 确保了岩芯不受外力作用而发生扭曲、变形. HQ 钻孔位于鹤庆盆地中的云鹤县城西南角的一块空地上 (图 1), 取样点海拔高度为 $2200 \mathrm{~m}$, 全井总长 $737.72 \mathrm{~m}$, 取芯率高达 $97 \%$. 在所获得的 $737.72 \mathrm{~m}$ 岩芯中, 除底部 $17 \mathrm{~m}$ 为湖盆形成初期的底砾岩外, 其余 岩芯基本为连续的湖相沉积.

本文仅对 $155 \mathrm{~m}$ 以上样品进行孢粉研究. 该段岩芯的岩性除顶部 $5 \mathrm{c} \mathrm{m}$ 为黑色富含有机质泥、1.16$1.36 \mathrm{~m}$ 处为灰褐色砂层外, 其余岩芯为较均一的湖相沉积, 以青灰色泥为主, 中间间有灰黄色泥, 在 $5.57-$ $27.21 \mathrm{~m}$ 和 $38.14-46.04 \mathrm{~m}$ 之间含螺壳及其碎片与植物残体.

孢粉样品取样间距为 $20 \mathrm{c} \mathrm{m}$, 共计 783 个样品. 实验室孢粉前处理采用 $\mathrm{HCl}-\mathrm{HF}$ 处理、过篮分选的方 法, 并用外加石松狍子定量测定孢粉浓度, 统计的狍粉分别用百分比和浓度表示.

钻孔年代由 ${ }^{14} \mathrm{C}$ 测年和古地磁极性柱来确定: ${ }^{14} \mathrm{C}$ 年龄 3 个, 由中国科学院南京地理与湖泊研究所湖泊 沉积与环境重点实验室测定, 它们分别是: $1.45 \mathrm{~m}$ 为 $5885 \pm 110 \mathrm{a} \mathrm{BP} ; 3.5 \mathrm{~m}$ 为 $11858 \pm 370 \mathrm{a} \mathrm{BP} ; 8.11 \mathrm{~m}$ 为 $30586 \pm 1120 \mathrm{a} \mathrm{BP}$. 古地磁测试由中国科学院西安地球环境研究所完成, Blake 事件 $0.123 \mathrm{Ma}$ 在 $24.62 \mathrm{~m}$; B/ $\mathrm{M}$ 界线 $0.78 \mathrm{Ma}$ 在 $152.12 \mathrm{~m}$. 样品的年代根据 ${ }^{14} \mathrm{C}$ 和古地磁年代进行线性插值得到.

\section{3 孢粉分析结果}

在研究的 783 个孢粉样品中, 共鉴定出 266 个孢粉 (科) 属 (种), 其中包括 3(科) 属藻类. 所有样品孢粉 丰富, 共统计到 488884 粒孢粉, 平均统计 624 粒/样, 最多统计了 1375 粒/样, 最少为 270 粒/样. 孢粉组合中 


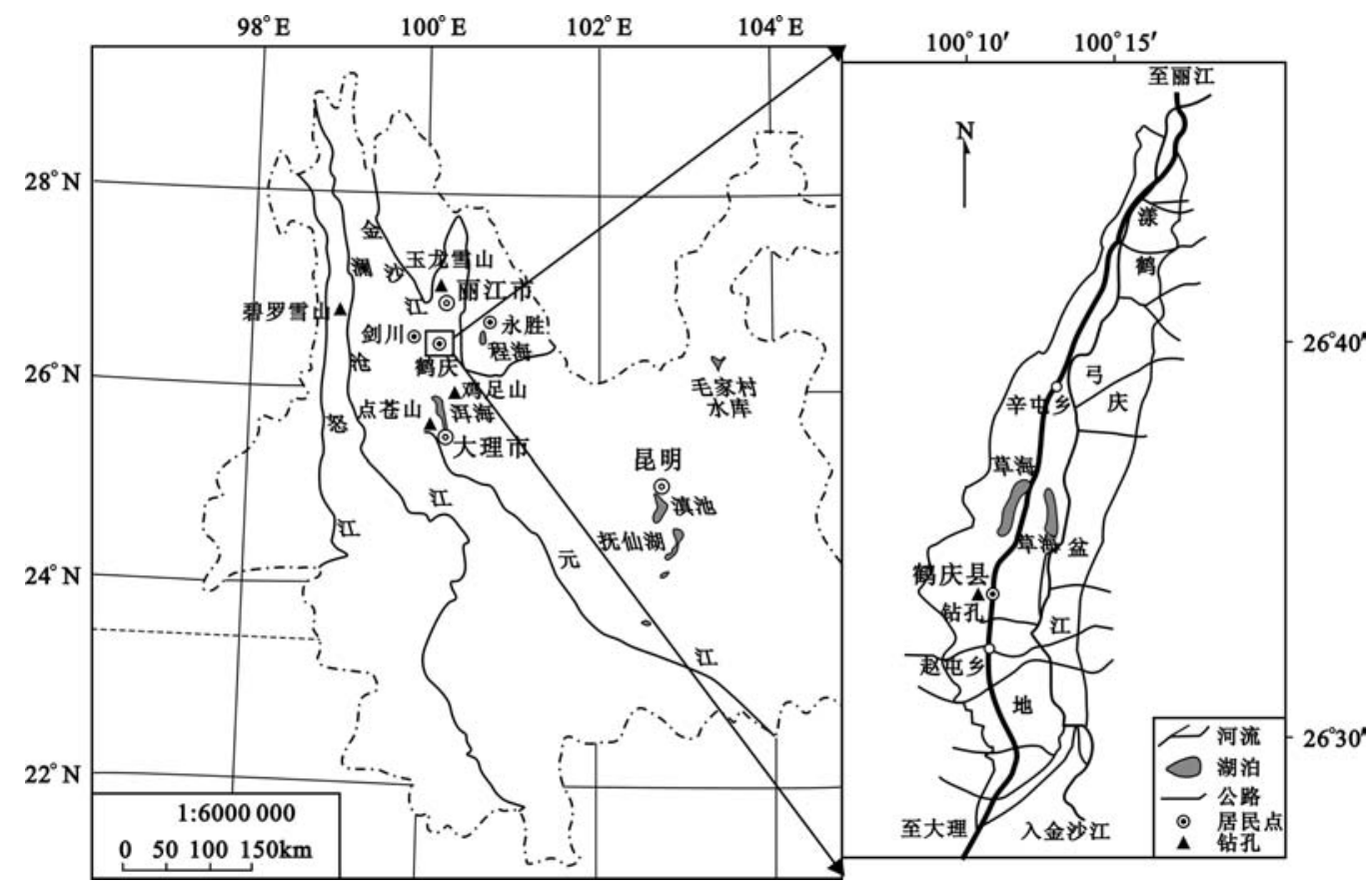

图 1 鹤庆钻孔位置图

Fig. 1 Location of HQ core

以乔木花粉为主, 百分比平均达到 $82.3 \%$, 最高为 $98.5 \%$, 其次为旱生草本, 平均为 $9.4 \%$, 灌木、水生草本、 莿类均较少. 在乔木花粉中松属 (Pinus) 占绝对优势, 平均含量为 $70.1 \%$, 其次云杉属 (Picea)、冷杉属 (Abies)、铁杉属 (Tsuga)、杉科( Taxodiaceae)、柏科(Cupressaceae)、油杉属 (Keteleeria)、雪松属 (Cedra)、桦属 (Betula)、榆属 (Ulmus)、胡桃属 (Juglans)、落叶栋属 ( Quercus)、常绿栋 (Evergreen oaks)、石栎属 (Lithocarpus)、栗属 (Castanea)、栲属 (Castanopsis) 等有一定含量; 灌木花粉主要有绣线菊属 (Spiraea)、南天竹属 (Nandina)、猕猴桃属 (Actinidia) 和木犀属 (Olea) 等; 旱生草本花粉主要有禾本科(Gramineae)、蒿属(Artemisia)、藜科(Chenopodiaceae)、毛茛属 (Ranunculus)、玄参科 (Scrophulariaceae)、唇形科( Labiatae)、白花菜科 (Capparidaceae)、苦苣苔科(Gesneriaceae)、伞形科(Umbelliferae)、百合 (Lilium) 等;水生草本(包括湿生)主 要是莎草科 (Cyperaceae) 和狐尾藻属 (Myriophyllum); 萍类狍子以铁线硕属 (Adiantum)、水龙骨科 (Polypodiaceae)、水龙骨属 (Polypodium) 以及瓦韦属 (Lepisorus) 为主; 盘星藻属 (Pediastrum) 在剖面上部含量较多.

为了便于统计制图,我们把生态意义相近的云、冷杉归为一类,水龙骨科的水龙骨属、瓦韦、石韦都归为 水龙骨科; 难以区分的石栋、栗、栲归为一类,柏科、杉科归为一类, 同时由于石栋/栗/栲的曲线趋势与常绿 栋的非常相似,所以把石栋/栗/栲及常绿栋合并为常绿柇类(其中可能含有落叶栋成份栗), 然后选择在剖 面中总的百分含量超过 $5 \%$ 而且生态意义较大的科属绘制狍粉图谱(图 2), 根据剖面的狍粉组合特征, 参考 聚类分析 Coniss 结果, 将本剖面孢粉组合划分为五个狍粉带, 其下又分成相应的狍粉亚带. 各带的狍粉组合 特征按由老到新的顺序简述如下:

孢粉带 I ,155-119.4 m (约 800-611 kaBP) : 孢粉组合为松 - 落叶栋 - 常绿栋类 - 蒿 (Pinus - Quercus - Evergreen oaks - Artemisia). 本带狍粉总浓度相对较低, 平均为 23224 粒/g, 以乔木花粉为主, 但灌木和旱 生草本花粉相对整个剖面含量较高. 乔木花粉以松占优势, 平均含量为 $69.1 \%$; 云/冷杉和铁杉含量都较 低, 平均仅 $1.8 \%$, 但铁杉含量在本狍粉带有两个峰值区, 最高可达 $22.8 \%$; 落叶栋在整个剖面中含量是最 高的, 峰值为 $7.1 \%$; 油杉和常绿栋类含量也相对较高, 平均分别为 $0.9 \%$ 和 $3 \%$; 有少量桦和榆. 本带的蒿在 整个剖面中含量最高, 峰值为 $16.3 \%$; 禾本科也有一定含量. 


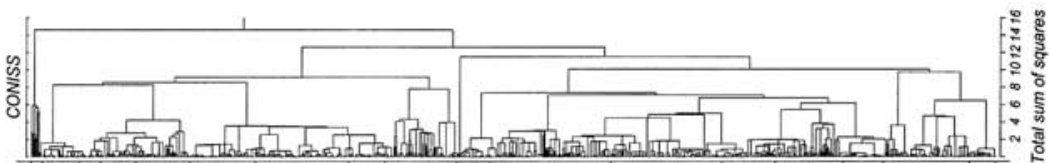

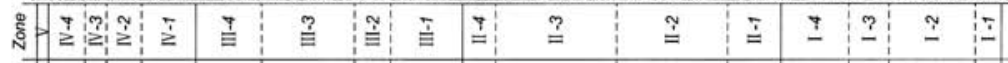

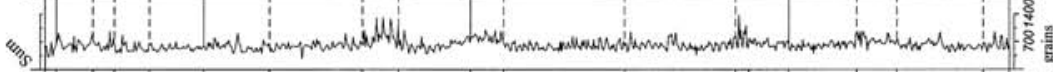

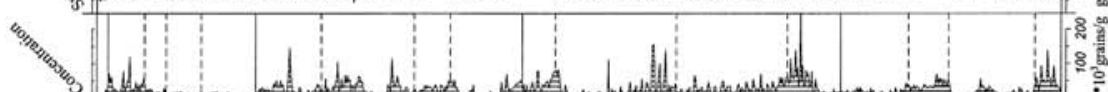

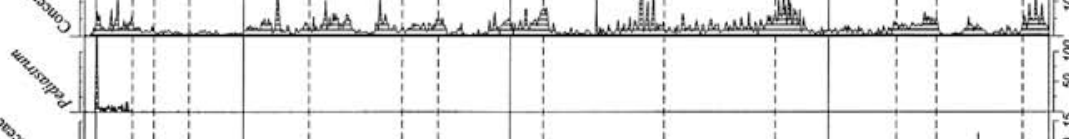

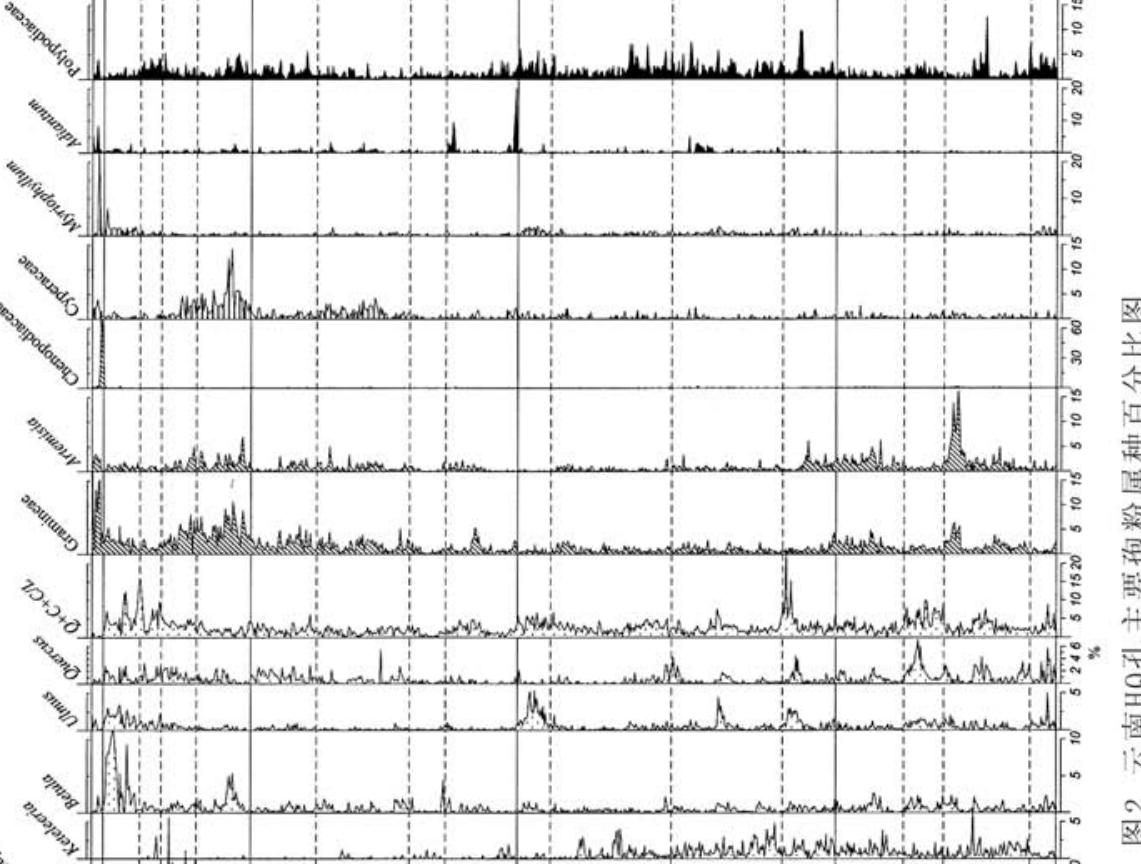

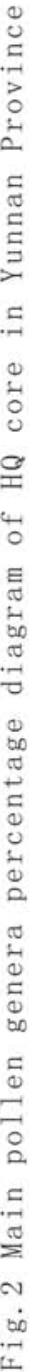

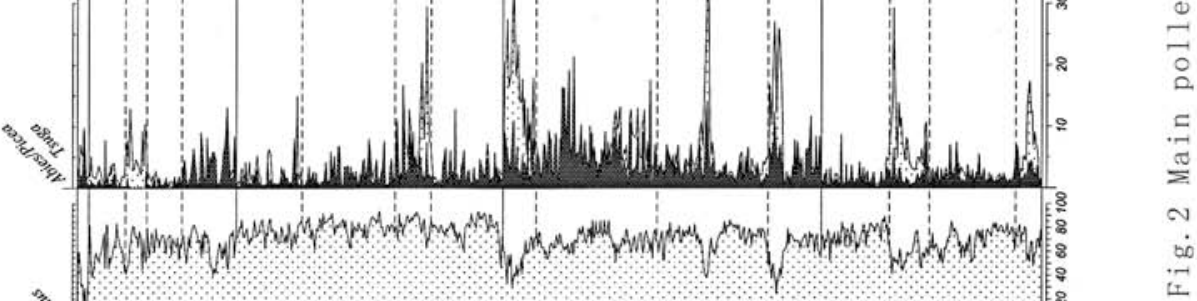

(I)

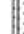

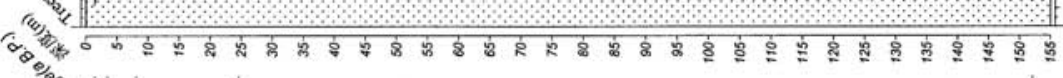

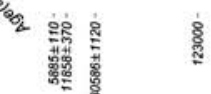


根据带内孢粉组合的波动情况可分成 4 个狍粉亚带. 其中亚带 I -1 (155-150. $72 \mathrm{~m}$, 即约 $800-773$ $\mathrm{kaBP}$ ) 和亚带 I -3 (136.8-130.32 m, 即 $701-668 \mathrm{kaBP})$ 的孢粉组合特征相似, 都是孢粉总浓度较高, 铁杉、 落叶栋和常绿栋类含量也都处在较高值, 而油杉、禾本科和蒿的含量都低; 亚带 I -2 (150.72-136.8 m, 即 $773-701 \mathrm{kaBP})$ 和 I -4 (130.32-119.4 m, 即 668-611 kaBP) 的狍粉组合特征则基本与亚带 I -1 和 I -3 相 反, 即油杉、禾本科和蒿含量较高, 而孢粉总浓度、铁杉、落叶栋和常绿栋类含量都较低.

孢粉带 II , 119.4-68.48 m(611-349 kaBP) : 孢粉组合为松 - 云/冷杉或铁杉 - 常绿栋类 (Pinus - Picea/Abies or Tsuga - Evergreen oaks). 本带可以进一步划分成以下 4 个亚带:

亚带 II -1 ,119.4-110.85 m(611 - 567 kaBP ) : 本亚带狍粉总浓度向上迅速增加, 云/冷杉花粉含量在 $119.4 \mathrm{~m}$ 处突然增加到 $11.6 \%$, 然后又逐渐减少, 在 $113.23-110.85 \mathrm{~m}$ 之间又先后出现铁杉和云/冷杉花粉 含量的峰值, 此期同时也出现了榆属、落叶栋、常绿栎类和狍粉总浓度的峰值. 油杉在本亚带含量相对较高 而稳定, 平均为 $1.2 \%$, 而禾本科与蒿属花粉含量从亚带底部向上逐渐减少至仅偶见.

亚带 II - 2 110.85-93.14 m(567 - 476 kaBP) : 孢粉总浓度较低, 并且波动不大, 亚带内除了在 $102.11-$ $99.55 \mathrm{~m}$ 之间先后出现铁杉和云/冷杉花粉含量峰值, 以及榆、落叶栋和常绿栋类的相对较高值外, 其它层 位的孢粉含量较稳定而且具较低的云/冷杉、铁杉花粉含量.

亚带 II -3,93.14-73.81 m(476-376 kaBP) : 亚带底部的孢粉总浓度较高, 向上逐渐降低,松平均含量 为 $69.8 \%$, 云/冷杉花粉在整个剖面中含量最高, 平均为 $6 \%$, 在 $79.91 \mathrm{~m}$ 处云/冷杉花粉突然增加到 $21.2 \%$ 的最高值, 铁杉花粉含量在 $93.14-85.29 \mathrm{~m}$ 之间含量较高, 向上减少至仅偶见, 油杉花粉含量从此亚带向 上逐渐减少至少见,而其它狍粉属种含量低且波动不大.

亚带 II -4,73.81-68.48 m(376-349 kaBP) : 孢粉总浓度高, 平均为 39577 粒 $/ \mathrm{g}$, 松属含量低, 最低为 $31.1 \%$, 平均为 $54.3 \%$, 铁杉、云/冷杉含量较高, 先后出现峰值, 榆属在整个剖面中含量最高, 常绿栎类含 量也相对较高.

孢粉带 III ,68.48 - 25.59 m(349-128 kaBP) : 孢粉组合为松 - 禾本科(Pinus - Gramineae). 本带孢粉 总浓度较带 II 有所降低, 平均为 26029 粒 $/ \mathrm{g}$, 以松属花粉为主, 其含量高且波动较小, 平均含量为 $79.4 \%$, 铁 杉、云/冷杉含量除了在 56.94 - 51. $14 \mathrm{~m}$ 处先后出现 $22.1 \%$ 和 $16.1 \%$ 的峰值外, 其它层位含量都较低, 平均 分别为 $1.9 \% 、 0.7 \%$. 根据带内孢粉的波动可进一步把该带划分成 4 个亚带: 亚带 III -1 (68.48-56.94 m, 即 $349-290 \mathrm{kaBP}$ )、亚带 III -3(51.14 - 36.14 m, 即 $260-182 \mathrm{kaBP})$ 和亚带 III -4 (36.14-25.59 m, 即 $182-128$ $\mathrm{kaBP})$ 的孢粉组合特征基本相似,差别在于亚带 III -1 的孢粉总浓度比后两者要低; 亚带 III -3 出现了少量湿 生草本莎草科,而另两带少见;亚带 III -4 中云/冷杉花粉含量较前两亚带相对要少, 而铁杉含量相对稍有增 加. 亚带 III -2 (56.94-51.14 m, 即 290-260 kaBP) 的孢粉组合特征与其它亚带相差较大, 其木本花粉平均 含量高达 $94.6 \%$, 是整个剖面木本花粉含量最高的层位; 铁杉、松和云冷杉花粉含量也都较高, 分别先后出 现峰值,其它属种的孢粉含量在整个剖面中处于最低值.

孢粉带 IV ,25.59-1.82 m(128-6.98 kaBP) : 孢粉组合为松 - 云/冷杉或铁杉 - 桦 - 常绿栋类 - 禾本 科(Pinus - Abies/Picea or Tsuga - Betula - Evergreen oaks - Gramineae). 本狍粉带由以下 4 个亚带组成:

亚带 IV -1 25.59-16.82 m(128-79 kaBP) : 孢粉总浓度很低, 平均仅 8587 粒 $/ \mathrm{g}$, 松属含量比带 III 减少 较多, 云/冷杉含量突然增加, 出现 $12.9 \%$ 的峰值, 铁杉少见, 桦属首次出现了 $5.4 \%$ 的小峰值, 常绿栎类含 量较上带变化不大, 禾本科和蒿含量增加, 莎草科在整个剖面中含量最高.

亚带IV -2 , 16.82-11.15 m(79-48 kaBP) : 孢粉总浓度仍然较低, 松属含量稍有增加, 云/冷杉含量迅速 减少至仅偶见, 铁杉花粉仍然很少, 出现较多的杉/柏科, 其峰值为 $16.9 \%$, 桦属减少至仅偶见, 常绿栋类有 所增加, 禾本科、蒿和莎草科逐渐减少.

亚带IV-3 , 11. $15-7.69 \mathrm{~m}(48-28.87 \mathrm{kaBP})$ : 狍粉总浓度逐渐增加, 松属含量平均为 $63.5 \%$, 云/冷杉 少见, 铁杉含量较高, 峰值为 $12.6 \%$, 杉/柏科含量比上亚带有所降低, 其它属种含量与亚带 IV -2 顶部相差 不多.

亚带 IV -4 ,7.69-1.82 m(28.87-6.98 kaBP) : 孢粉总浓度比较高, 平均为 39830 粒 $/ \mathrm{g}$, 松属含量向上逐 渐减少, 平均为 $61.9 \%$, 云/冷杉又零星出现, 铁杉含量降低, 平均仅 $1.4 \%$, 此期桦属含量在整个剖面中含 
量最高, 峰值为 $11.8 \%$, 常绿栋类含量也相对较高, 并且首次出现了较多的盘星藻, 峰值出现在亚带的顶 部, 杉/柏科、榆属和落叶柇以及水生草本狐尾藻也有一定含量.

孢粉带 $\mathrm{V}, 1.82-0 \mathrm{~m}$ (6.98 $\mathrm{kaBP}$ 至今) : 孢粉总浓度迅速降低, 平均仅 6127 粒 $/ \mathrm{g}$, 乔木花粉含量先急 剧下降后又有所上升, 最低为 $18 \%$; 旱生草本含量增加较多, 在 $14.2 \%-83.4 \%$ 之间; 水生草本和茨类都有 所增加. 其中阔叶乔木花粉桦属、榆属、落叶栋和常绿栋类等迅速减少至偶见, 松属含量先迅速降低到 $1.45 \mathrm{~m}$ 处的最低值 $9.2 \%$, 然后又增加, 此时出现藜的最高值 $77.2 \%$, 在 $1.05 \mathrm{~m}$ 处云/冷杉又出现了一次 $8.8 \%$ 的峰值和狐尾藻 $25.2 \%$ 的峰值, 禾本科含量迅速增加, 在整个剖面中是最高值, 蒿和莎草科略有增 加, 盘星藻突然消失.

\section{4 植被生态与古植被、古气候恢复}

松生长在较低海拔的山坡,性偏干暖,一般认为,松含量的增多在西南季风区指示温度的升高和降水的 减少 ${ }^{[7]}$. 由于它是超显示花粉, 有人认为当其含量在 $30 \%$ 以下时, 并不见林子存在 ${ }^{[8,9]}$, 而本剖面中松含量 大多超过 $30 \%$, 显然松在本文中研究古植被演替时具有代表意义. 在我国西南山地, 云杉、冷杉林分布区气 候寒冷, 年平均温度指标为 $2^{\circ} \mathrm{C}$ (上限) $-8^{\circ} \mathrm{C}$ (下限 $)^{[10]}$, 年降水量低于 $1000 \mathrm{~mm}$, 大致在 $600 \mathrm{~mm}$ 左右 ${ }^{[4]}$. 铁 杉在云南属于温凉性针叶树种, 反映的是温凉潮湿的气候, 其分布区的年平均气温大致为 $8.4-10.5^{\circ} \mathrm{C}$, 年 平均降水量在 $1000 \mathrm{~mm}$ 左右,一般多在 $900-1000 \mathrm{~mm}$ 之间 ${ }^{[4]}$. 杉/柏科都既有偏温凉的属种又有耐干热的 属种, 本剖面中的柏科多数是偏温凉的属种, 而杉科不确定, 在本文中暂把杉/柏科视为反映温凉气候. 油杉 是暖温性针叶树种, 其分布地为中亚热带偏干的气候, 年平均温约 $10-17^{\circ} \mathrm{C}$, 年降雨量约 $700-1200 \mathrm{~mm}^{[4]}$. 中生温带落叶树种,包括胡桃、榆等, 指示夏季降水的增多, 与桦一样是冬季耐干冷的树种 ${ }^{[7]}$. 落叶栎对生 境条件要求不严, 适应性较强, 能耐干旱 ${ }^{[4]}$. 栲和石栎是目前该区中山湿性常绿阔叶林的主要成分, 分布在 海拔 $2900 \mathrm{~m}$ 以下, 指示较湿润的环境 ${ }^{[4]}$. 藜科和蒿所反映的环境一般比较干旱. 莎草科生长在湿地及其附 近, 它的大量出现反映沼泽化或潮湿的环境 ${ }^{[11]}$. 狐尾藻广泛分布于云南省各大湖泊、河沟、水塘中, 在较大 湖泊中, 多少成带状分布, 水深 $4 \mathrm{~m}$ 以内, 基质不限, 水质不拘 ${ }^{[4]}$. 盘星藻属是淡水水域较为常见的绿藻之 一, 生活于浅水湖泊、池塘、洼地或小河流, 一般水深不超过 $15 \mathrm{~m}^{[12,13]}$, 许多研究者指出, 盘星藻化石在地层 中的大量出现, 可作为淡水湖沼沉积的指示标志 ${ }^{[14]}$.

云南玉龙雪山表土狍粉显示 ${ }^{[15]}$, 寒温性针叶林中松含量一般为 50\%-80\%. 在海拔 $3050-4100 \mathrm{~m}$,云/ 冷杉花粉含量较高, 在 $0.37 \%-53.7 \%$ 之间, 平均为 $16.6 \%$, 海拔 $3050 \mathrm{~m}$ 以下, 云/冷杉花粉含量都低于 $3 \%$, 云/冷杉林带范围为 $3100-3900 \mathrm{~m}$, 说明本区的表土花粉与植被分布基本相应. 铁杉花粉在 $3090-$ $3180 \mathrm{~m}$ 之间含量较高, 在 $0.24 \%-10.8 \%$ 之间, 平均为 $4 \%$, 其峰值位于 $3100 \mathrm{~m}$ 左右, 对应现代植被中的残 存铁杉林.

根据以上常见属种的生态特征和表土花粉结果, 推测了中更新世以来鹤庆盆地周围山地的古植被与古 气候经历了以下五个大的阶段:

第一阶段,即约 800-611 kaBP:孢粉组合总体上反映此期周围山地为松林所占据,并混有常绿阔叶树 种常绿栋、石栋/栲等和落叶阔叶树种桦、榆、落叶栎等, 林中还间有暖温性针叶树油杉. 在此大的背景下, 植 被仍有变化,即在 $155-150.72 \mathrm{~m}$ 和 $136.8-130.32 \mathrm{~m}$ 两个时期内有较高铁杉含量, 说明这两个时期铁杉有 可能成林, 相当于现今 $3100 \mathrm{~m}$ 左右的植被. 表明这一阶段在总体气候暖干的背景下,有次一级的气候波动, 即由温凉较湿 $\rightarrow$ 暖干 $\rightarrow$ 温凉潮湿 $\rightarrow$ 温暖干旱的变化.

第二阶段,611-349 kaBP: 总体上为松与云/冷杉、铁杉交替变化时期. 云/冷杉在整个阶段都有发育, 有时成林, 有时仅零星分布; 而铁杉与云/冷杉稍有不同, 为间断分布, 即有时成林, 有时少见. 反映气候波动 较大, 存在多次冷湿、暖干旋回. 具体表现为: 在 $113.23-110.85 \mathrm{~m} 、 102.11-99.55 \mathrm{~m} 、 93.14-85.29 \mathrm{~m}$ 和 $73.81-68.48 \mathrm{~m}$ 几个时段内, 铁杉和云/冷杉林发育, 并且都是先以铁杉林为主, 然后逐渐转向以云/冷杉林 为主, 同时林中间有榆、落叶栋和常绿栋类等. 反映在气候上这几个时段都是由温凉潮湿逐渐向冷偏湿转 化, 说明气温是逐渐下降的. 在 $119.4 \mathrm{~m}$ 和 $79.91 \mathrm{~m}$ 处, 云/冷杉花粉含量突然增加, 与其相对应的孢粉总浓 度、铁杉花粉及其它落叶与常绿属种含量都很低, 说明气候突然变冷, 并且幅度较大, 既不利于落叶阔叶属 
种与常绿润叶属种的生长, 也不适合温凉性针叶树铁杉的生长, 植被为以云/冷杉为主的寒温性针叶林. $110.85-102.11 \mathrm{~m}$ 和 $99.55-93.14 \mathrm{~m}$ 两个时段的植被类型是以松为主的针叶林, 林中零星分布有云/冷 杉, 偶见油杉和常绿栋类, 表明气候较暖偏干.

第三阶段,349-128 kaBP:孢粉组合反映植被类型大部分为以松为主的针叶林, 但在 56.94-51.14 m 时段内, 植被由以松为主的针叶林演替成云/冷杉、铁杉为主的针叶林. 表现在气候上经历了温暖较干 $\rightarrow$ 温 凉湿润至寒冷偏湿, 中间间有短暂的暖干时期 $\rightarrow$ 温暖偏干 $\rightarrow$ 温暖干旱四次转化. 岩性特征表明在 46. $04-$ $38.14 \mathrm{~m}$ 之间出现了螺壳及碎片, 而螺壳层是岸滩沉积物, 指示湖泊变浅, 这与气候变暖是相应的.

第四阶段, $128-6.98 \mathrm{kaBP}$ : 本阶段的狍粉组合反映植被类型经历了四次明显的演替, 即寒温性针叶林 $\rightarrow$ 以松为主的针叶林 $\rightarrow$ 山地针阔叶混交林, 此期铁杉有可能成林, 少见云/冷杉, 林内间有常绿柇类等树种 $\rightarrow$ 由松、华和常绿栋类等组成的针阔叶混交林. 相应地气候也经历了四次变化: 由一开始的寒冷较湿润, 冬 季降水较少逐渐转向温暖干旱; 然后向温凉潮湿转化, 此期相当于现今 $3100 \mathrm{~m}$ 左右高度的气候; 到本阶段 末期气温升高, 夏季降雨较多而冬季偏干, 但总体上有效湿度比前期要低, 湖泊水位下降, 逐渐向浅水湖泊 转化. 这与岩性特征中 $5.57-27.21 \mathrm{~m}$ 之间含螺壳及碎片指示的湖泊变浅相符.

第五阶段, $6.98 \mathrm{kaBP}$ 至今:孢粉组合反映植被在 $6.98 \mathrm{kaBP}$ 时发生了转折性变化, 森林植被迅速退化, 以草本为主. 阔叶乔木突然消失, 针叶树松先迅速减少然后又有一定恢复, 草本中的禾本科、蒿增加明显. 显 示此期人类活动的参与, 早期的人类活动大多从砍伐森林开始, 因此在沉积物孢粉组合特征上,通常表现为 木本花粉百分含量的突然降低以及相应草本花粉的增加. 松花粉含量先迅速减少后又有一定恢复, 说明此 期气候较适宜, 在人类活动砍伐后又较快的生长成次生林. 在 $1.82 \mathrm{~m}$ 处盘星藻突然消失指示湖泊环境发生 了明显改变,推测可能是此时湖盆被切开导致湖水流失不利于盘星藻生长, 这与从 $1.82 \mathrm{~m}$ 开始, 中值粒径、 碳酸盐和烧失量急剧变小 ${ }^{[16]}$ 相应, 这与以前的结果 ${ }^{[17]}$ 也是一致的. 随后在 $1.45 \mathrm{~m}$ 和 $1.05 \mathrm{~m}$ 处分别出现藜 科和狐尾藻的峰值, 可能指示自 $6.98 \mathrm{kaBP}$ 湖盆切开后至 $4.67 \mathrm{kaBP}$ 有一个较短的干旱期, 随后降雨增加, 钻孔所在地附近有一定积水, 适合狐尾藻的生长, 而 $1.05 \mathrm{~m}$ 处云/冷杉的峰值可能指示短暂的降温. 但总体 上狍粉组合反映此阶段的气候为温暖较湿润.

\section{5 讨论与结论}

$\mathrm{HQ}$ 孔中更新世以来的狍粉组合揭示出周围山地的植被类型在约 $800 \mathrm{kaBP}$ 至 $6.98 \mathrm{kaBP}$ 之间经历了以 松为主的针叶林、山地针阔叶混交林、寒温性针叶林等的多次相互演替, 在这三种大的植被类型背景下, 其 植被组成仍有变化; 从 $6.98 \mathrm{kaBP}$ 开始, 植被发生了转折性变化, 森林植被迅速退化, 以草本为主, 此时开始 受到人类活动的影响, 人类活动表现在砍伐森林和种植农作物等方面, 这与最近的研究结果 ${ }^{[18]}$ 相符.

山地垂直带谱的变化一般反映了区域性植被的纬向分异, 尽管鹤庆盆地化石孢粉包含了垂直带谱的混 合信息, 但其狍粉结果仍清楚地揭示了与植被演替相应的中更新以来该区的古气候经历了多次冷暖、干湿 旋回. 冷、暖期的气候组合特征是在 $29 \mathrm{kaBP}$ 以前为冷湿、暖干, $29 \mathrm{kaBP}$ 以后组合特征发生了明显转变, 成 为暖偏湿的气候组合. 该区冷湿、暖干气候组合与东部季风区 ${ }^{[19,20]}$ 、西北干旱区 ${ }^{[21,22]}$ 的冷干、暖湿气候组合 特征存在明显差异; 与青藏高原区的若尔盖研究结果也不尽相同,若尔盖 RM 孔多环境指标的研究结果 ${ }^{[23]}$ 表明自中更世以来该区的气候组合类型经历了四次大的变化:900 - 795 ka 的暖湿、冷干组合;795 - 480 ka 的暖干 - 冷湿组合; $480-162 \mathrm{ka}$ 的暖偏干 - 冷偏干组合; $162 \mathrm{ka}$ 以来的暖湿 - 冷干组合 ${ }^{[24]}$. 本区的气候组 合与其它地区存在的差异显示了本区具有显著的区域特点, 我们认为, 这种区域环境效应与云贵高原的地 貌部位、青藏高原隆升导致的西南季风区大气环流变化和青藏高原地表反照率变化引起的热力学和动力学 过程有关. 同时该区的古气候演化具有明显的阶段性, 其阶段与孢粉组合的分带相对应, 即阶段 I (对应带 I , 约 800-611 kaBP) 气候总体上为暖干, 期间间有两次相对较短的温凉湿润期; 阶段 II (对应带 II ,611 $349 \mathrm{kaBP}$ )气候不稳定,存在多次冷湿、暖干波动,而且波动幅度较大; 阶段 III (对应带 III , 349-128 kaBP), 气候较稳定,除了在 56.94-51. $14 \mathrm{~m}$ 之间气候转向温凉湿润至寒冷偏湿外其它时期均为暖干; 阶段 IV (对 应带 $\mathrm{V}, 128$ - 6.98 kaB. P. ), 气候又有冷暖波动, 但幅度不如阶段 II 大; 阶段 V (对应带 V,6.98 kaBP 至 今), 气候总体上温暖较湿润. 
本剖面中的云/冷杉花粉含量高值区都对应着冷偏湿的气候,而铁杉花粉含量高值区都对应温凉潮湿 气候.一般来说, 在云/冷杉和铁杉花粉含量高值层位中松属花粉含量低,其它狍粉属种种类较多而且含量 相对较高,但孢粉亚带 III-2(290 - 260 kaBP) 与其它层位有所不同, 虽然此亚带云/冷杉、铁杉花粉含量高, 但其松属花粉含量没有降低, 而且木本花粉含量是整个剖面中最高的, 其它孢粉属种种类少而且含量极低. 说明此期在整个剖面中是一个很重要的界线, 在此以前冷暖波动较频繁而且幅度较大, 此后虽然仍有冷暖 波动,但幅度不再如前.

致谢 成文过程中得到羊向东研究员的指导, 王苏民研究员对本文提出宝贵的修改意见, 在此深表感谢!

\section{6 参考文献}

[1] 中国科学院南京地理与湖泊研究所等主编. 云南断陷湖泊环境与沉积. 北京: 科学出版社, 1989.

[2] 王苏民, 张振克. 中国湖泊沉积与环境演变研究的新进展. 科学通报, 1999, 44(6) : 579-587.

[3] 沈 吉, 王苏民, Matsumoto $\mathrm{R}$ 等. 内蒙古岱海古水温定量恢复及其古气候意义. 中国科学 $\mathrm{D}$ 辑, 2001, 31(12) : 1017 - 1023.

[4] 云南植被编写组编著. 云南植被. 北京: 科学出版社, 1987: 417, $771-773$.

［5］云南省鹤庆县志编纂委员会. 鹤庆县志. 昆明: 云南人民出版社, 1991: 85-111.

[6] 云南省林业调查规划院. 云南自然保护区. 北京: 中国林业出版社, 1989: $200-214$.

[7] Jarvis D I. Pollen evidence of changing Holocene monsoon climate in Sichuan Province, China. Quaternary Research, 1993, 39: $325-337$.

［8］孙湘君, 吴玉书. 云南滇池地区全新世以来植被及环境变迁历史. 见: 中国科学院中澳第四纪合作 研究组编. 中国 - 澳大利亚第四纪学术讨论会论文集. 北京: 科学出版社, 1987: $28-41$.

[9] 夏玉梅. 呼伦贝尔沙地古土壤孢粉特征与大暖期环境的初步研究. 中国生存环境历史演变规律研究 (一). 北京: 海洋出版社, 1993: $44-53$.

[10] 中国植被编辑委员会. 中国植被. 北京: 科学出版社. 1980: 176-179.

[11] Sun X J, Luo Y, Huang F. Deep-sea pollen from the South China Sea: Pleistocene indicators of east Asian monsoon. Marine Geology, 2003, 201: $97-118$.

[12] 萧家仪, 吴玉书, 郑绵平. 西藏扎布耶盐湖晚第四纪狍粉植物群的初步研究. 微体古生物学报, 1996, $13(4)$ : 395 - 399.

[13] 张 华, 郑 卓, 王建华等. 海南岛近 2500a 来盘星藻记录的周期性气候变化. 热带地理, 2004,24 (2) : $109-123$.

[14] 张玉兰, 张敏斌. 海洋沉积物中淡水藻的发现及其古环境意义. 海洋通报, 2002, 21 (2): $36-40$.

[15] 童国榜, 羊向东, 刘志明等. 云南玉龙山地区的表土花粉散布特征. 海洋地质与第四纪地质, 2003, $23(2): 103-107$.

[16] 肖海丰, 沈 吉, 肖霞云. 云南鹤庆盆地 2. 8 Ma 以来的构造演化. 湖泊科学, 2006,18 (3): 255 -260 .

[17] 蒋雪中, 王苏民, 羊向东. 云南鹤庆盆地 $30 \mathrm{ka}$ 以来的古气候与环境变迁. 湖泊科学, 1998, 10 (2): $10-16$.

[18] 沈 吉, 杨丽原, 羊向东等. 全新世以来云南洱海流域气候变化与人类活动的湖泊沉积记录. 中国科 学( D 辑), 2004, 34(2): $130-138$.

[19] 王伟铭, 虞子冶, 杨 浩. 江西星子县第四纪红土层的植硅石和狍粉研究及意义. 微体古生物学报, 1997, 14(1): $41-48$.

[20] 许 坤, 石敦久. 辽东湾北部晚新生代的古植被与古气候. 海洋地质与第四纪地质, 1997, 17(1): 25 - 32.

[21] An ZS, Kukla G, Porter SC, Xiao JL. Magnetic susceptibility evidence of monsoon variation on the loess plateau of central China during the last 130,000 years. Quaternary Research, 1991, 36: 29 - 36.

[22] Burbank DW, Li JJ. Age and paleoclimatic significance of the loess of Lanzhou, North China. Nature, 1985, 316: $429-431$.

[23] 施雅风, 李吉均, 李炳元. 青藏高原晚新生代隆升与环境变化. 广州: 广东科技出版社, 1998: 180 $183,408$.

[24] 沈才明, 唐领余, 王苏民等. 若尔盖盆地 RM 孔孢粉记录及其年代序列. 科学通报, 2005, 50 (3) : $246-253$. 